\title{
Are we not peasants too? Land rights and women's claims in India
}

Bina Agarwal

Follow this and additional works at: https://knowledgecommons.popcouncil.org/departments_sbsr-pgy

Part of the Family, Life Course, and Society Commons, International Public Health Commons, Place and Environment Commons, and the Rural Sociology Commons How does access to this work benefit you? Let us know!

\section{Recommended Citation}

Agarwal, Bina. 2002. "Are we not peasants too? Land rights and women's claims in India," SEEDS no. 21. New York: Population Council. 


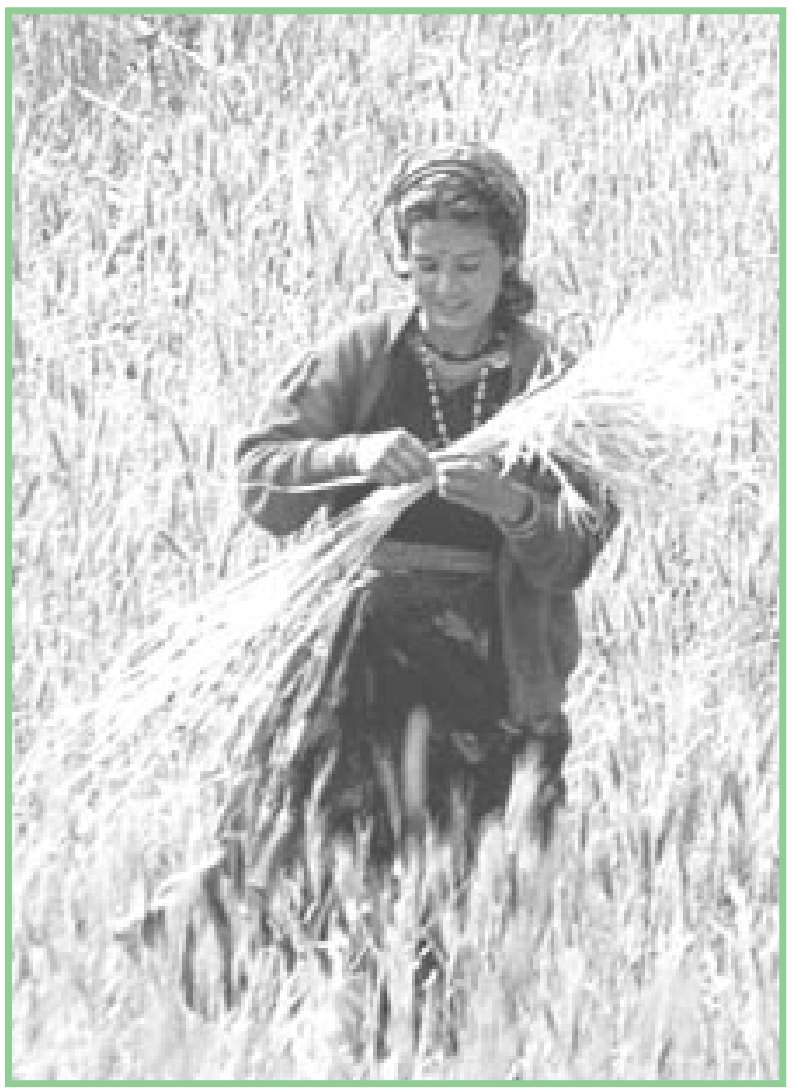

\section{Are We Not PeasantsToo? Land Rights and Women's Claims in India}

by Bina Agarwal

\section{About the Author}

Bina Agarwal is Professor of Economics at the Institute of Economic Growth, University of Delhi, and author of the award-winning book A Field of One's Own: Gender and Land Rights in South Asia. Her work has had national and international impact, within both academic and policy circles, on the neglected issue of women's rights in property, especially land. 


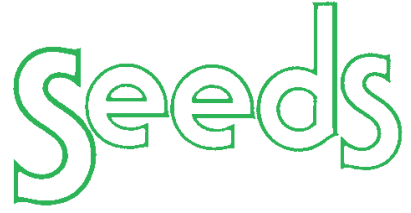

is a pamphlet series developed to meet re-

quests from all over the world for information about innovative and practical program ideas developed to address the economic roles and needs of low-income women. The pamphlets are designed as a means to share information and spark new initiatives based on the positive experiences of projects that are working to help women generate livelihoods and to improve their economic status. The projects described in this and other issues of SEEDS have been selected because they have served not only to strengthen women's productive roles, but also to integrate women into various sectors of development, both social and economic. All projects documented in the SEEDS series involve women in decisionmaking, organize women locally, and address broader policy issues that affect the economic roles of women.

These reports are not meant to be prescriptive, since every development effort will face somewhat different problems and possibilities. Rather, they have been written to describe the history of an idea and its implementation in the hope that the lessons learned can be useful in a variety of settings. They are also being written to bring to the attention of those in decisionmaking positions the vital roles that women play not only in the economies of their individual households but also in the economic life of every nation.

This edition of SEEDS is made possible by support of the Ford Foundation, the Rockefeller Foundation, and the Population Council.

\section{QPopulation Council}

The Population Council is an international, nonprofit, nongovernmental institution that seeks to improve the well-being and reproductive health of current and future generations around the world and to help achieve a humane, equitable, and sustainable balance between people and resources. The Council conducts biomedical, social science, and public health research and helps build research capacities in developing countries. Established in 1952, the Council is governed by an international board of trustees. Its New York headquarters supports a global network of regional and country offices.

Population Council, One Dag Hammarskjold Plaza, New York, New York 10017 USA tel: (212) 339-0500, fax: (212) 755-6052, e-mail: pubinfo@popcouncil.org http://www.popcouncil.org.

Statements made and views expressed in this publication are solely the responsibility of the author and not of any organization providing support for SE EDS. Any part of this document may be reproduced without permission of the author so long as it is not sold for profit.

Number 21, $2002 \quad$ ISSN: 073-6833

Copyright (c) 2002 The Population Council, Inc. 


\section{Foreword}

SEEDS is pleased to publish our twentyfirst issue, Professor Bina Agarwal's Are We Not Peasants Too?, exploring the critical elements in securing effective and independent land rights for women. Although the author's primary focus is South Asia, the analytical framework and proposed action plan are of relevance to Latin America, Africa, the Caribbean, and eastern Europe-indeed wherever women's use and control of arable land are crucial to their economic well-being and livelihoods. SEEDS issues 10, 14, and 16 provide readers with additional background to several topics discussed here, with particular reference to Nepal, Zambia, and India.

Are We Not Peasants Too? documents the substantial and enduring barriers and biases obstructing efforts to strengthen women's relationship to the resourcegenerating asset of land. Despite the centrality of this issue to reducing rural women's poverty and improving their economic status, the author shows why women's independent claims to land have been difficult to achieve, even where progressive social movements and legal reforms have recognized them, such as in India.

To tackle such obstacles, Professor Agarwal presents a range of cooperative strategies for enabling women to retain and cultivate the land and shows how micro-credit and other programs can be redirected to increase the amount and productivity of land women control. Recognizing that new policies and political will are required to foster and sustain such experiments, the author ends with a summary of how women are organizing to place women's access to land at the center of national and global agendas.

In this spirit, SEEDS hopes that Are We Not Peasants Too? will inspire grassroots women's groups, NGOs, innovative donors, policymakers, and others from around the world to share examples of how they have established strategies that increase women's access to this crucial asset. Let us hear from you!

- Sandy Schilen, SE EDS Editor 


\section{Are We Not Peasants Too? Land Rights and Women's Claims in India}

by Bina Agarwal

\section{Introduction}

In 1979, over two decades ago, a group of poor women from West Bengal made the following demand of their elected village council: "Please go and ask the government why, when it distributes land, we don't get a title. Are we not peasants? If my husband throws me out, what is my security?" ( personal communication, Vina Mazumdar, 1992). This demand underlined these women's clear recognition that their families alone could not guarantee them economic security. What they also needed were fields of their own.

\section{A Neglected Issue}

In largely agrarian economies, arable land is the most valued form of property and productive resource. It is a wealth-creating and livelihood-sustaining asset. F or a significant majority of rural households it is the single most important source of security against poverty. Traditionally, it has been the basis of political power and social status. For many, it provides a sense of identity and rootedness. It is an asset that has a permanence that few other assets possess. In some communities, ancestral land also symbolically stands for continuity of kinship and citizenship.

While many of these links are well recognized at the household level, their importance specifically for women has received little attention. Indeed, the issue of women's rights in land ( and more generally in property) has been, until recently, largely neglected in both research and policy. In fact, in almost all developing countries, large-scale surveys and agricultural censuses collect property-related information only by households, without disaggregating by gender. Nepal is a recent exception where such data will now be collected in its census. In most of South Asia, including India, therefore, we still have to depend on small-scale surveys and village studies to assess women's access to land. These sources reveal that typically few women own arable land and even fewer effectively control some.

The social and economic implications of this are wide-ranging. Millions of women in Asia, Africa, and Latin America depend critically on land for a livelihood. The typical process of agrarian transformation under which labor shifts from agriculture to nonagriculture has been slow and gender-biased. In many countries, those who have moved to nonfarm work are largely men, while women have remained substantially in agriculture. Hence a disproportionate number of those still dependent on land are women. In India, for instance, 58 percent of all male workers but 78 percent of all female workers, and 86 percent of all rural female workers, are in agriculture. Indeed the gender gap has been growing. Women's domestic work burden, lower mobility, lesser education, and fewer investable assets limit their entry into nonagriculture, and also their range of nonfarm options. Moreover, the nature of women's agricultural work is, to a 
greater extent than for men, casual in nature. Relative to men, women also continue to have lower real wage rates and lower average real wage earnings in both agriculture and nonagriculture.

As more men shift to urban or rural nonfarm livelihoods, a growing number of households will become dependent on women managing farms and bearing the major burden of family subsistence. The percentage of de facto female-headed households is already large and growing. Estimates for India range from 20 to 35 percent. These include not just widows and deserted and separated women, but also women in households where the men have migrated out and women are effectively farming the land. These women will shoulder (and many are already shouldering) growing responsibilities in agricultural production but will be constrained seriously by their lack of land titles.

Moreover, the male biases in land ownership and transfers that have been noted in many developing countries are in danger of being replicated in new land reform initiatives and property rights formulations. For instance, agrarian reform is a major policy issue in postapartheid South Africa; and new private property rights in land and other assets are now being constituted in Eastern Europe and the former USSR. Here new gender inequalities are already being created (Meer 1997; Verdery 1996).

It is therefore timely and essential to examine in more detail why it is important for women to have effective and independent land rights, what obstructs their realizing their claims, and what could be done to improve the situation. While these issues are discussed here largely in the Indian or the South Asian context, many are also relevant to other developing regions and to the transition economies. And although the focus here is on arable land, since that is such a crucial form of property and means of liveli- hood in South Asia, many of the arguments and concerns could be extended to cover women's rights in a dwelling house or in other forms of property.

\section{Defining Land Rights}

Rights (in any form of property) are defined here as claims that are legally and socially recognized and enforceable by an external legitimized authority, be it a village-level institution or some higherlevel body of the State. Land rights can stem from inheritance, transfers from the State, tenancy arrangements, land purchase, and so on. They can be in the form of ownership or usufruct (rights of use), and can encompass differing degrees of freedom to lease out, mortgage, bequeath, or sell.

Three additional distinctions are relevant here. First, there is a difference between the legal recognition of a claim and its social recognition, and between recognition and enforcement. A woman may have a legal right to inherit property, but this may remain merely on paper if the claim is not recognized as socially legitimate or if the law is not enforced. Second, there is a distinction between ownership and effective control. It is sometimes assumed incorrectly that legal ownership carries with it the right of control in all its senses. In fact, legal ownership may be accompanied by restrictions on disposal, as among the J affna Tamils of Sri Lanka and several communities in Latin America, where a married woman needs her husband's consent to alienate the land she legally owns. Third, we need to distinguish between rights vested in individuals and those vested in groups.

Our concern here is with women having effective and independent rights in land, effective rights being rights not just in law but also in practice; and independent rights being rights that women enjoy in their own capacity and independent of those enjoyed by men. 


\section{Why Land Is Important for Women}

My bangles are broken, my days of shame are gone. I have one small son, one calf, onefield. A calf to feed, a son to nurture but the field, baiji [sister] this half acre of earth

to feed me, to rest my head.

- Malli, a Rajasthani widow

(author's interviews, 1987)

E ffective and independent land rights for women are important on at least four counts: welfare, efficiency, equality, and empowerment.

\section{Welfare}

It is well accepted that land access can notably reduce a household's risk of poverty, but for several reasons land solely in men's hands need not guarantee female welfare.

First, there are persistent gender inequalities and a bias favoring males in the distribution of resources within households, including allocations for basic necessities such as health care, education, and, in some regions, even food. Biases in food and health care are revealed especially in anthropometric measures (e.g., weight and height for age, weight for height, etc.), morbidity rates, and most starkly in female-adverse sex ratios.

In contrast, direct land transfers to women are likely to benefit not just women but also children. Evidence both from India and from many other parts of the world shows that women, especially in poor households, spend most of the earnings they control on basic household needs, while men spend a significant part of theirs on personal goods, such as alcohol, tobacco, etc. (Dwyer and Bruce 1988). This, in turn, affects child welfare. Children in rural India are found more likely to attend school and receive medical attention if the mother has more assets (Duraisamy 1992). Among marginal farmer households in Kerala ( south India), the mother's cultivation of a home garden (the output of which she controlled) was found to have a consistently high positive effect on child nutrition (Kumar 1978). In urban Brazil, the effect on child survival probabilities was found to be several times greater when asset income accrued to the mother, compared with when it accrued to the father, and the positive effect on the health of daughters was especially high (Thomas 1990). A part from differences in spending pat-

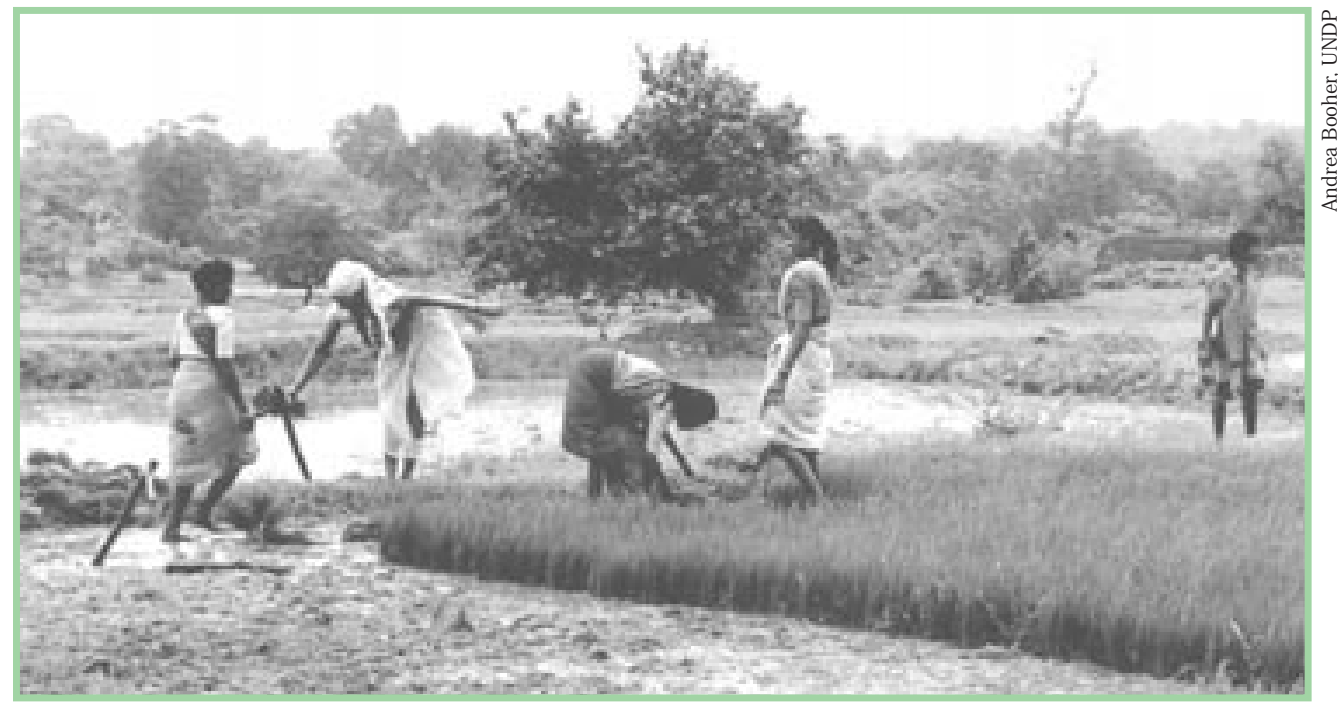


terns, women with assets such as land have greater bargaining power, which can lead to more gender-equal allocations of benefits even from male incomes. In short, women's and children's risk of poverty would be reduced and their welfare enhanced if women had direct access to land, and not just access mediated through male family members.

Second, women without independent resources are highly vulnerable to poverty and destitution in case of desertion, divorce, or widowhood. In parts of western and northwestern India, not uncommonly, rural women even from rich parental and marital families, deprived of their property shares when widowed, can be found working as agricultural laborers on the farms of their well-off brothers or brothers-in-law. The fate of deserted and divorced women is worse.

Relatives, including sons and brothers, often do not provide the expected economic security to women who are widowed or whose marriages break down. Many of them end up living on their own. In fact, mortality risks among widows tend to be higher among those living as dependents of male relatives compared with those who are heads of households, and who presumably have some independent means of subsistence (Rahman and Menken 1990). Indeed, for widows and the elderly entitlement to family care can depend critically on whether they have property to bequeath. As the elderly often say: "Without property children don't look after their parents well" (Caldwell et al. 1988: 191).

Land can provide women both direct and indirect benefits. Direct advantages can stem from growing not just crops, but trees, a vegetable garden, or grass for cattle. Indirect advantages arise in various ways: owned land can serve as collateral for credit or as a mortgageable or saleable asset during a crisis. Land ( whether owned or controlled by women) also increases the probability of wom- en finding supplementary wage employment, and serves as an important asset base for rural nonfarm enterprises. For instance, those with land are found to

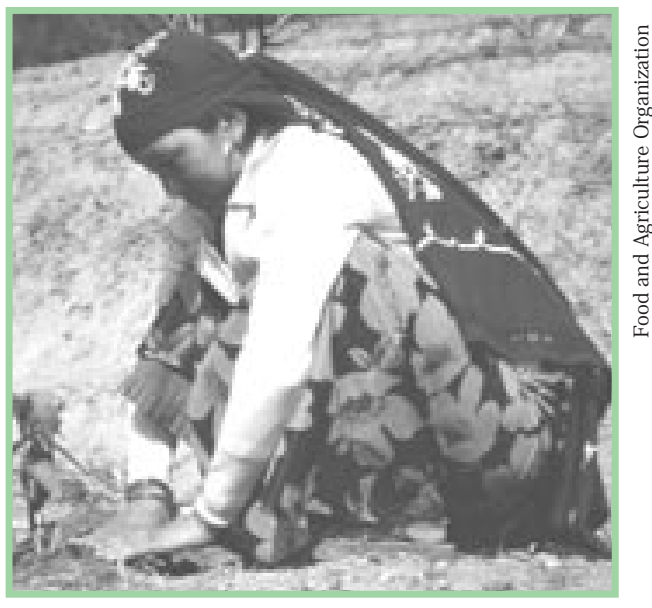

generate much higher rural nonfarm earnings from self-employment than the totally landless (Chadha 1992). In short, women's access to even a small plot can be a critical element in a diversifi ed liveli hood system, and can signifi cantly i mprove women's and the family's welfare, even if the plot is not large enough to provide full family subsistence. And independent access to land will become increasingly important for women as marital and kin support erodes, and female-headed households multiply.

\section{Efficiency}

In addition to welfare gains, more gender-equal land rights could also enhance productive efficiency. First there is an incentive effect. Although it is widely recognized that security of tenure can be critical for motivating farmers to make productivity-enhancing investments in their fields, the need for si milar incentives within the family has been large ly ignored. Some recent studies suggest that incentives could be as important within families. In Kenya, for example, 
where men and women often cultivate separate plots, the introduction of weeding technology in maize production raised yields on women's plots by 56 percent where women controlled the output, and only by 15 percent on their husbands' plots, where women also weeded but men got the proceeds (EIson 1995). Whether similar results will obtain in India and other countries will require field testing and analysis. But the Kenya results provide an important pointer to the outputenhancing potential of secure land rights for women and of their control over produce.

Second, where land access is in the form of titles ( which serve as collateral in many regions), secure rights for women would help increase output by improving women's access to credit. This can prove especially crucial in situations where women are the principal farmers, as where male out-migration is high, or where widows (or wives) are cultivating separate plots still formally owned by kin.

Third, research from some other parts of the world suggests that women might use land more efficiently than men in certain contexts. In Burkina Faso, for instance, due to their choice of cropping patterns women achieved much higher values of output per hectare on their own plots than their husbands did on theirs (Udry et al. 1995). Although women's yields for given crops were lower than men's, this was due to their lesser access to inputs such as fertilizers which were concentrated on the men's plots. The study estimated that output could be increased by as much as 10-20 percent if such inputs were reallocated from plots controlled by men to those controlled by women in the same household. A literature review of the effect of gender on agricultural productivity in several countries of Africa and Asia also concludes that output could be increased notably if women farmers had the same access to inputs and education as male farmers (Quisumbing 1996).
Fourth, women in many parts of South Asia are often better informed than men about traditional seed varieties and the attributes of trees and grasses. If they had greater control over land and farming, this knowledge could be put to better use.

Fifth, tenure security, and especially titles can empower women to assert themselves better with agencies that provide inputs and extension services.

While welfare arguments for women's land rights have received some policy attention, there is yet little recognition

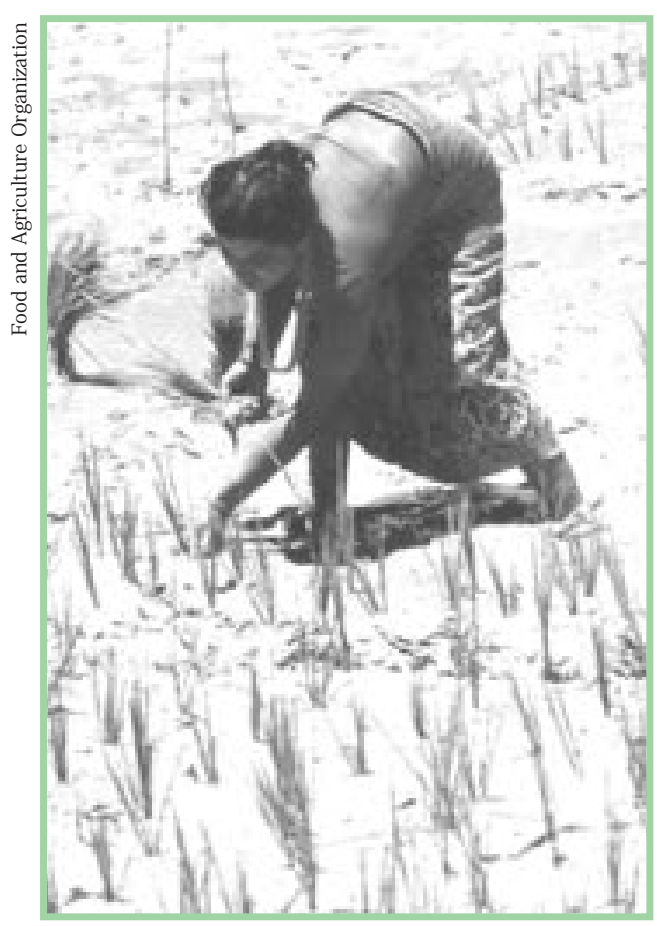

of the potential positive effects on efficiency. In fact, some argue that land transfers to women will have a negative efficiency effect, in that such transfers will reduce output by reducing farm size and increasing fragmentation. However, there is no noteworthy evidence of an adverse size effect on output. In fact, in India and other parts of South Asia, small farms are found to have a higher value of output per cultivated unit than large farms (Banerjee 2000); and frag- 
mentation can arise equally with male inheritance. Also, where necessary, farmers have dealt with fragmentation in various ways: consolidation through purchase and sale; land leasing arrangements to bring together cultivation units even where ownership units are scattered; and joint investment and cultivation by small groups. In India, as a result of these measures, the number of fragments per farm has declined from 5.7 in 1961 to 2.7 in 1991.

It is thus important to contest a priori negative efficiency arguments, such as the fragmentation argument, which are typically put forward only in relation to women's claims to inheritance, but not in relation to men's claims. Equally, the positive productivity effects of more genderequal land access, and of greater tenure security and access to inputs for women farmers, found in some existing studies, need emphasis, even while expanding the base of empirical analysis. As noted, these positive effects could be especially important in regions of high female headedness, or where the feminization of agriculture is moving apace as more men than women enter nonfarm occupations.

\section{Equality and Empowerment}

The equality argument is an important one in and of itself, since gender equality is a measure of a just and progressive society. But, in addition, equality in land rights is a critical element in women's economic empowerment. The word "empowerment" is now widely used in the literature, usually without being defined. Here empowerment is defined "as a process that enhances the ability of disadvantaged ('powerless') individuals or groups to challenge and change (in their favor) existing power relationships that place them in subordinate economic, social and political positions" (Agarwal 1994: 39).

Endowing women with land would empower them economi cally as well as strengthen their ability to challenge social and political gender inequities. An illustrative example is women's experience in the Bodhgaya struggle in Bihar (eastern India). Here, in the late-1970s, women and men of landless households jointly agitated for ownership rights in the land they cultivated, which was under the illegal possession of a Math (a temple-monastery complex). During the movement, women demanded independent land rights, and received them in two villages, with marked implications. In the villages where men alone received titles, women's insecurity grew, with an increase in men's tendency to threaten wives with eviction in situations of domestic conflict: "Get out of the house, the land is mine now" (Manimala 1983: 15). But where women got titles they graphically described their feeling of being empowered: "We had tongues but could not speak, we had feet but could not walk. Now that we have the land, we have the strength to speak and walk" (Alaka and Chetna 1987: 26). (Also see Box 1.)

This sense of empowerment accompanying improved land rights also enhances women's ability to assert themselves within the home, in the community, and with the State.

From the preceding discussion it is clear that land rights can serve multiple functions in rural women's lives which are not easy to repli cate through other means. This is important to keep in mind since the present thrust of most national and international agencies is not on land rights but on micro-credit programs which are being promoted as a panacea, especially (but not only) for poor rural women. Although credit is clearly an important need for poor women, many individual women not only face problems in retaining control over such loans, but the privileging of this one form of support over all other livelihood sources can prove problematic and diversionary. A number of evaluations show that such 


\section{Box 1}

\section{The Bodhgaya Movement}

The Bodhgaya movement, initiated in 1978 in the Gaya district of Bihar, was a struggle by landless laborers and sharecroppers to gain rights in land which they had cultivated for decades. The land, some 9,575 acres spread over 138 villages, was held by a Math (a monastery-cum-temple complex), much of it in violation of land ceiling laws. Math officials exploited the peasants and also sexually abused the women. The struggle emerged under the leadership of the Chatra Yuva Sangharsh Vahini, a Gandhian-socialist youth organization founded in 1975 by Jayaprakash Narayan (a contemporary of Mahatma Gandhi) and committed to improving the lot of the disadvantaged. Vahini membership was restricted to those under thirty, and included women in every tier of the organization.

The movement lasted several years. Its primary slogan was J o zameen ko boye jote, voh zameen ka malik hai (those who sow and plough the land are the owners of the land). Women played a crucial role in the movement. In 1980, for instance, the activists decided to seize the land and cultivate it independently of the Math. About 3,000 acres were captured and ploughed. Despite police attacks, sowing was completed. At harvest time, the attacks were renewed. Since women usually harvested the crops, it was they who faced the brunt. As the repression intensified, women's involvement increased. Women also participated in the movement's nonviolent protests, despite threats of beatings and rape by the Math's hired ruffians. Over time, women began participating in equal numbers with the men and also courting arrest with accompanying children.

In addition, women organized shivirs (camps) to discuss their concerns within the struggle. They focused on women's exploitation, their exclusive responsibility for housework, discrimination against girl children, men's verbal and physical violence against them, and (most importantly) women's need for independent land rights. Resolutions were passed, including one against wifebeating and another demanding land in women's own names.

Finally in 1981, the government identified 1,000 acres of the Math's land for redistribu- tion to the agitating farmers. The Vahini drew up a list, giving priority to landless laborers, the disabled, widows, and small peasants. Women other than widows did not figure in the list, and they protested their exclusion: "We were in the forefront of the fight, carrying our children in our wombs and in our arms. We went to jail and faced the lathis [sticks]; we also did all the housework. But when the land was distributed, we were pushed back, we didn't even come to know by what rules the land was distributed" (Manimala 1983: 15).

After a prolonged debate on why women should have independent land rights, in 1982 it was decided that women too would receive land in their own names in future distribution. In two villages the villagers unanimously approved lists for giving land only to women and widowers. But the District Officer in charge of registering the titles strongly opposed this, arguing that there was no precedent for giving land to persons other than heads of households, who were typically men. The villagers, however, refused to take any land unless it was given to women.

Almost three years passed before women were finally allocated land. In time, all the Math's illegal holdings were distributed and women received land in various ways: individual titles, joint titles with husbands, as widows, destitute and disabled persons, and (without precedent) in some cases as unmarried adult daughters. Although such women were few since most girls there were married before they were eighteen, the idea that unmarried daughters were eligible was an important step forward. Each person received about one acre.

How did all this come about? Initially, women encountered opposition at three levels: from husbands, from the Vahini activists, and from government officials. Women's ability to overcome these layers of opposition depended on several factors: men's recognition over time that women's contributions were crucial to the movement's success; the growing solidarity among women and their articulation of their gender-specific interests as distinct from those of the men of their class and community; the support of some 
middle-class female Vahini activists with a feminist perspective; and the process of debate in which women persuasively countered opposition.

For instance, when the women protested against their exclusion from the Vahini's initial list of land recipients, the men argued: "What difference does it make in whose name the land is registered?" The women responded: "If it doesn't make a difference, then put it down in the woman's name. Why argue about it?" To the suggestion that women's demand would weaken class unity, the women replied: "Equality can only strengthen, not weaken an organization, but if it does weaken our unity, that will mean that our real commitment is not to equality or justice but to the transfer of power, both economic and social, from the hands of one set of men to the hands of another set of men." When the men asked: "How can you cultivate the land on your own? Who will plough it for you?" they replied: "Well, who will harvest your crop in that case? We are ready to cultivate the land with hoes instead of ploughs, but we want it in our names" (Manimala 1983).

Indeed the significance of the Bodhgaya struggle from women's perspective lies not just in its being South Asia's first land struggle where women's land interests received explicit attention. It also lies in the process by which this was achieved. It is noteworthy that a largely illiterate peasant community discussed at length issues such as women's independent rights in economic resources, domestic violence, female education, and postmarital residence, and on several counts resolved them in women's favor. The debate, although arduous, brought significant rewards. The question of gender equality began to be seen by many not as divisive but as integral to the movement's success. As a result, women's participation in decisionmaking also increased, wife-beating and verbal abuse against women was deemed shameful, and male villagers began to take care of cooking and childcare in the women's shivirs, while the women participated in discussions.

The Bodhgaya women were also indirectly helped by a growing women's movement and a spreading feminist consciousness in the country in the late 1970s and early 1980s, when issues concerning women's rights were being raised in various forums. In contrast, women in the Tebhaga movement of the 1940s (see Box 2) had not demanded independent land rights. At that time, there was an absence of cohesiveness among women on gender questions; a lack of spokespersons among them who could articulate a feminist perspective; and the absence of a widespread women's movement in the country. For the Bodhgaya women, the situation was favorable on all these counts. They were thus able to articulate their interests overtly. However, the Bodhgaya experience still awaits replication. credit programs do not reach the poorest households, let alone change the gender balance in property ownership and control. In fact a recent study for Bangladesh (cited in IFAD 2001) identified a lack of access to land and homesteads as major factors in the exclusion of the poorest from credit NGOs.

An alternative to the existing approach of promoting micro-credit for non-landrelated micro-enterprises is to link land and micro-credit by providing rural women who depend on land-based livelihoods with credit for leasing in or purchasing land in groups (as discussed later). Here micro-credit would complement rather than substitute for efforts to enhance women's land rights. But this would require a significant shift from the existing focus of most micro-credit programs.

\section{Women's Land Access in Practice}

To what extent do women have effective land rights in practice? Consider the three major ways by which women can gain land: inheritance, State transfers, and the market. Of these, inheritance is the most important, since in most countries arable land is largely privatized. In India, 86 percent of arable land is privately held. Moreover, efforts to pro- 


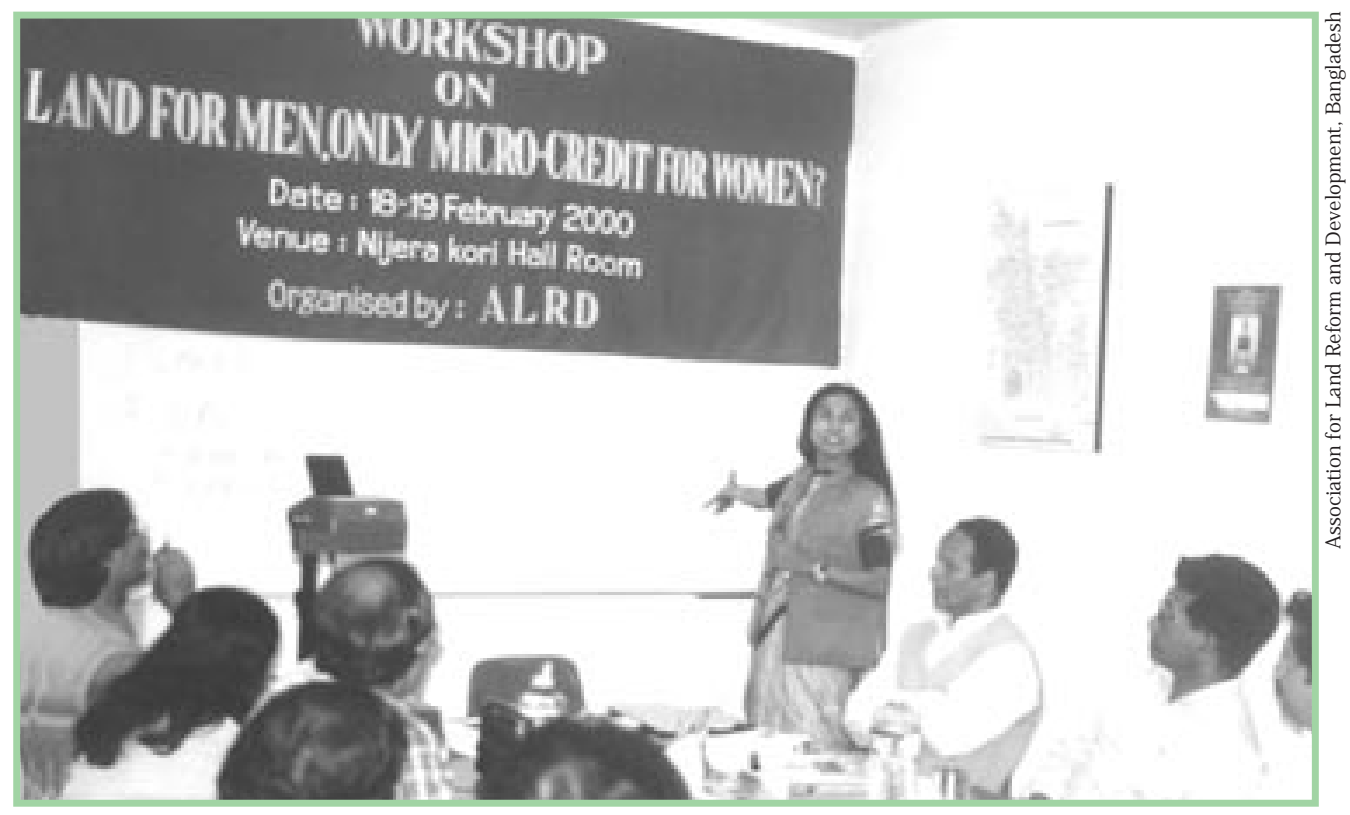

mote gender equality in inheritance are important for ensuring that the land obtained through the government or the market does not pass solely to male heirs in the next generation.

\section{Inheritance}

It is not easy to determine how many women inherit land in practice, given the noted absence of gender-disaggregated land ownership data at the all-India level. To assess ownership patterns, we therefore have to depend on small-scale studies. These can nevertheless be revealing, such as a 1991 sample survey of rural widows by Martha Chen covering seven states (Table 1; see also Chen 2000). Chen found that of the 470 women with landowning fathers, only 13 percent inherited any land as daughters. (Regionally, the figure ranged from 18 percent in south India to 8 percent in north India.) For all-India this means that 87 percent of the surveyed women did not receive their legal due as daughters.

Women as widows fared somewhat better. Of the 280 widows whose deceased husbands owned land, 51 percent inherited some. But this still means that half the widows with legal claims did not inherit anything. And of those that did, typically their shares were not recorded formally in the village land records. Other studies have shown that where the land is so recorded, invariably the widow's name is entered jointly with adult sons, who effectively control the land. The popular perception is that the widow's share is for her maintenance and not for her direct control or use. Widows without sons rarely inherit. Moreover, widows in India constitute only about 11 percent of rural women, 76 percent of whom are over 50 years old, many of them too old to effectively work the land. Hence inheritance as widows does not compensate women for their being disinherited as daughters.

\section{Government Transfers}

A second potential source of land for women is State transfers. These transfers can be part of land reform programs, resettlement schemes for those displaced by large dams and other projects, or antipoverty programs. Irrespective of the program under which the transfers occur, typically 
Table 1 Rural W idows W ho Inherited Land as Daughters and as W idows

\begin{tabular}{|c|c|c|c|c|c|c|c|}
\hline \multirow[b]{2}{*}{ Region/ State } & \multirow{2}{*}{$\begin{array}{r}\begin{array}{r}\text { Total } \\
\text { sample }^{\mathbf{a}}\end{array} \\
\text { No. }\end{array}$} & \multirow{2}{*}{$\begin{array}{r}\begin{array}{r}\text { Father } \\
\text { owned land }\end{array} \\
\text { No. }\end{array}$} & \multicolumn{2}{|c|}{$\begin{array}{l}\text { Women who inher- } \\
\text { ited as daughters }\end{array}$} & \multirow{2}{*}{$\begin{array}{r}\begin{array}{r}\text { Husband } \\
\text { owned land }\end{array} \\
\text { No. }\end{array}$} & \multicolumn{2}{|c|}{$\begin{array}{l}\text { Women who inher- } \\
\text { ited as widows }\end{array}$} \\
\hline & & & No. & $\%$ & & No. & $\%$ \\
\hline $\begin{array}{l}\text { Northern India } \\
\text { Bijar }\end{array}$ & $\begin{array}{r}262 \\
71\end{array}$ & $\begin{array}{r}229 \\
70\end{array}$ & $\begin{array}{r}18 \\
2\end{array}$ & $\begin{array}{l}8 \\
3\end{array}$ & $\begin{array}{r}193 \\
57\end{array}$ & $\begin{array}{l}98 \\
16\end{array}$ & $\begin{array}{l}51 \\
28\end{array}$ \\
\hline Rajasthan & 49 & 42 & 2 & 5 & 39 & 27 & 69 \\
\hline Uttar Pradesh (hills) & 50 & 50 & 1 & 2 & 45 & 23 & 51 \\
\hline West Bengal & 92 & 67 & 13 & 19 & 52 & 32 & 62 \\
\hline $\begin{array}{l}\text { Southern India } \\
\text { Andhra Pradesh }\end{array}$ & $\begin{array}{r}283 \\
79\end{array}$ & $\begin{array}{r}241 \\
77\end{array}$ & $\begin{array}{l}43 \\
12\end{array}$ & $\begin{array}{l}18 \\
16\end{array}$ & $\begin{array}{l}87 \\
37\end{array}$ & $\begin{array}{l}45 \\
18\end{array}$ & $\begin{array}{l}52 \\
49\end{array}$ \\
\hline Kerala & 104 & 65 & 28 & 43 & 15 & 10 & 67 \\
\hline Tamil Nadu & 100 & 99 & 3 & 3 & 35 & 17 & 49 \\
\hline All regions & $545^{b}$ & 470 & 61 & 13 & 280 & 143 & 51 \\
\hline
\end{tabular}

Source: Martha Chen (personal communication of results from her 1991 survey).

${ }^{a}$ For all states, other than Kerala, the sample consists only of Hindu widows. In Kerala, it also includes some Muslim matrilineal households.

${ }^{b}$ This is a subsample consisting of currently widowed women. The original sample had 562 ever-widowed women spread over 14 villages, two each in the seven states listed.

the land is allotted almost exclusively to males, even in communities which traditionally practiced matrilineal inheritance, such as the Garos of northeast India.

Also this bias is found no matter which political party is in power. In West Bengal, for instance, in the late 1970s and early 1980s the Communist Party of India (Marxist), which was then in power, carried out "Operation Barga" - a major land reform initiative which sought to secure the rights of tenants by systematically registering them. However, it primarily registered men. Land distributed to the landless also went almost entirely to men. Although an exception was supposed to be made for single-women householdsthose divorced, deserted, and without adults sons- few qualifying single women received land in practice. A village in Midnapur district studied by Gupta (1993) is indicative. She found that 98 percent of the 107 holdings distributed went to men. In nine out of ten femaleheaded households the land went to the women's sons; and only eight of the eighteen single women received land. Married women did not receive even joint titles.

This male bias has a long history. Historically, even in peasant movements in which women were significant participants, they were not recognized as inde- pendent claimants to land. The Tebhaga and Telangana movements of the 1940s are cases in point (see Box 2 on the former). Exceptions to this pattern are few and far between, one being the earliermentioned 1970s Bodhgaya struggle, in which women demanded and received independent land shares in two villages.

In the more recent period, a few of India's Five Year Plans have given some recognition to women's land claims. For instance, the Eighth Five Year Plan (1992-97) directed state governments to allot 40 percent of ceiling surplus land to women alone and the rest jointly to both spouses. (This was land acquired by the government from those owning more than a permissible ceiling.) The Ninth Five Year Plan (1997-2000) went further in terms of policy formulation. In its chapter on poverty alleviation it incorporated many of the author's recommendations on promoting group rights and collective farm management for women, along with providing infrastructural support. It also recognized the need for collecting gender-disaggregated information on land ownership and use.

The crunch, however, lies in whether state governments are willing to implement these recommendations. Also the ceiling surplus land available for distribution is extremely limited: it came to only 


\section{Box 2}

\section{The Tebhaga Story}

The Tebhaga movement emerged in 1946-47 in undivided Bengal, in the footsteps of the great Bengal famine of 1943. Sharecroppers in the region had no occupancy rights and faced a constant threat of eviction. The landlords took half the produce while bearing no part of the production costs, levied illegal taxes, and sexually abused the women. The movement, spearheaded by the Bengal Provincial Kisan Sabha (BPKS), under the leadership of the Communist Party of India, demanded a reduction of land rents and an end to other forms of exploitation. The women's self-defense league played a critical mobilizing role among women.

Prior to the movement, sexual exploitation was closely linked to caste and economic oppression:

Li ke the mangoes of the [sharecropper's] trees, like the bananas of his garden, li kethe gourds of his thatched roof, like the eggplant from his garden, his daughters and daughtersin-law were the [landlord's] property.... If the [landlord] expresses his wish, the daughter or the wife of the [sharecropper] will be sent to the [landlord's] house. (a woman activist, quoted in Cooper 1988: 102)

Both Hindu and Muslim women participated in the movement in large numbers:

Women who remained in the villages during the day...[ warned] people of police arrivals by sounding alarms, blowing conch shells, for example. They provided shelter and food for activists. Women who frequently went to market became responsible in some areas for communication and carrying messages between organizers. In some villages there were special [women's corps] which guarded villages. Poor peasant women participated in meetings and demonstrations, joined delegations to landlords, and occasi onally members of Tebhaga committees, although not holding particular positions.

However, women's mi litancy was re membered mostly because of their actions to resist arrests, when they displayed incredible courage, initiati ve and heroism in rescuing people. (Cooper 1988: 270-271)

Women's weapons of resistance were household implements, the commonplace objects of their daily existence, with which they (often successfully) confronted the police:

As the poli ce entered the villages, bells and conch shells used to be blown and the echo could be heard from one end to the other.... It was the peasant womenfolk who organized this novel form of warning. Almost immedi ately on hearing this, all the womenfolk would take hold of broomsticks, lathis and their husking pestles... and form a barricade on the village road, so that the police could not enter. (Chakravartty 1980: 90)

In disarming police parties, in resisting arrests, and in rescuing people, women's initiatives assumed heroic proportions. On several occasions, attempts by landlords to appropriate the harvested paddy from the peasants' fields with police help were also thwarted by the women. For instance, in Kendemari village:

... they least expected that a militant group of [peasant] women... would advance with daos, choppers and broomsticks. Tied to their sareeends they carried a handful of dust, mixed with chilli powder. As they approached the police, they threw this powder in their eyes and the police ran for their lives. (Chakravartty 1980: 94).

Often, however, the confrontations were violent, and many courageous women were injured or killed in police firings.

During the campaign, several gender concerns were voiced, such as wife-beating. As one woman graphically put it: "[When] the husband and wife together are dying in the field, in the battle for Tebhaga; when the two together are fighting against the enemy, how then was it possible for one soldier to beat the other after returning home?" (cited in Custers 1987: 177). In some areas the cam- 
paign against domestic violence made a strong impact, but in others the culprits got off lightly. Especially in Muslim areas when male peasants objected to women attending the peasant committee meetings, some of the women retorted: "It does not hurt your sense of propriety when we sow or harvest in the fields along with you. How does it become objectionable when we want to attend kisan samiti meetings?" (cited in Custers 1987: 172). Objections nevertheless continued, and the issue was never resolved.

Despite women's participation, unequal gender relations persisted both within and outside the movement. Whatever gains women made were ad hoc. Their objections to domestic violence led to the boycott of some of the male activists responsible, but the issue was not seen as integral to the larger political struggle to change economic and social relations that the movement was addressing. In particular, women's rights in land were not discussed. Women also played little role in decisionmaking. And while during the most intense periods of the agitation women emerged from their domestic roles, they were forced to return to housework and largely unchanged gender relations within the family when the struggle ended. It was not until several decades later, during the Bodhgaya movement, that oppression within the family and women's rights in land emerged as significant concerns within a peasant movement in South Asia.
0.56 percent of India's arable land at the time of the Eighth Plan and today it comes to less than 0.2 percent of the country's arable land. Even in West Bengal, a state with the largest amount of area declared surplus to date, the total ceiling surplus land came to only 8.7 percent of the state's arable land, and today virtually none is left for distribution.

Hence while it is important to reduce biases in government land transfers, and thereby also to send the message that women's claims deserve attention, in terms of actual land area such transfers can go but a small way in improving Indian women's land status.

\section{Through the Market}

The third source of land for women is through lease or purchase. The weight of this option will depend on financial, institutional, and infrastructural support to women. In itself, this is a limited option since individual rural women seldom have access to adequate financial resources for this purpose. Also, in terms of purchase, rural land markets are often constrained and land is not always available for sale. For instance, an all-India study of land sales among a sample of landowning households in the early 1970s found that only 1.75 percent had sold any land during the survey year (Rosenzweig and Wolpin 1985). Another study, for Uttar Pradesh (northwest India) that examined land sales over a thirty-year period from the 1950s to the 1980s, found that only 4.1 percent of owned agricultural land had been sold (Shankar 1990). Hence for both sexes, the possibilities of purchasing land are limited, with women being especially constrained. Land purchase through the market thus cannot compensate for gender inequalities in inheritance or government transfers. There is somewhat greater potential for obtaining land on lease, since this is more readily available.

For both lease and purchase, however, external support to women would improve access. For instance, in parts of South Asia, groups of landless women have been using subsidized credit provided by the State, for leasing in or purchasing land in groups, and cultivating it jointly (as elaborated further below). Through such collective endeavor, land through the market could well prove an important supplementary means for women to acquire land, even if not the primary means. 


\section{O bstacles to Women's Land Access}

What obstructs women from gaining greater land access? While the difficulties that individual women face in getting land through the market were indicated above, those relating to private and government land are more complex.

\section{Privatized Land: Legal, Social, and Administrative Biases}

To my brother belong your green fi elds O father, while I am bani shed afar... - (Hindi folksong)

Always you said

Your brother and you are the same O Father. But today you betray me... My doli leaves your house.

- (folksong, personal communication

Veena Das)

\section{Inheritance laws}

In most of India, inheritance was traditionally patrilineal (that is ancestral property passed through the male line), with some limited matrilineal pockets (where ancestral property passed through the female line), as in northern and central Kerala in the south and Meghalaya in the northeast (Agarwal 1994, 1995). Among the majority Hindu community, for instance, the common pattern was for women to inherit only in the absence of male heirs, typically in the absence of four generations of men in the male line of descent. Widows had the first claim and daughters followed. What women received, however, was only a limited interest, that is, they enjoyed the property during their lifetime after which it reverted to the original source. Also women's rights of disposal were restricted: they could not mortgage, give, or sell the land, except in exceptional circumstances. In most cases, the rights of Muslim women in customary practice were very similar to those of Hindu women in their regions of location.
During the twentieth century, however, through the concerted efforts of women's organizations, liberal lawyers, and social reformers, inheritance laws shifted significantly toward gender equality. Although these efforts met with stiff resistance from many opinionmakers and politicians (including India's first President), the changes were facilitated by the historic moment. It was a time when the idea of building a modern forwardlooking nation was becoming part of the popular imagination. Also the first elected government of Independent India had a notable body of progressive professionals in Parliament, who supported the idea of gender-equal laws. As a result, most Indian women were able to negotiate much greater rights in postindependence law than they had had a century ago. For instance, the Hindu Succession Act (HSA) of 1956 made sons, daughters, and widows equal claimants in a man's separate property and in his share in the joint family property. It also gave women full control over what they inherited, to use and dispose of as they wished. Similarly, the Muslim Personal Law Shariat (Application) Act of 1937 substantially enhanced Muslim women's property rights compared with those prevailing under custom.

Yet, in both communities some notable inequalities remain. Both Hindu and Muslim inheritance laws, for instance, treat agricultural land differently from other property. The HSA exempted tenancy rights in agricultural land from its purview. Hindu women's inheritance in tenancy land thus depends on state-level tenurial laws, which in most northwestern states specify an order of devolution that strongly favors male agnatic heirs. Women come very low in the order of heirs, as was the case under age-old customs. Furthermore, these inequalities cannot be challenged on constitutional grounds because land reform laws come under the Ninth Schedule of the Consti- 
tution. This constitutional provision was meant to protect land reform laws from being challenged by entrenched class interests, but in the process (albeit unwittingly) it also entrenched gender inequality.

Likewise, the Shariat Act of 1937, applicable to Muslims in India, excluded all agricultural land (both tenanted and owned) from its purview. Subsequently, some of the southern states extended the provisions of this Act to also cover agricultural land. In all other regions, however, agricultural land, unlike other property, continues to devolve according to customs, tenurial laws, or other preexisting laws. In most of northwest India, such laws and customs give women's property rights very low priority.

A second source of inequality lies in the differential inheritance shares for men and women. In the HSA, for instance, although sons and daughters have equal shares in a man's separate property, there is also the continued recognition of joint family property in which sons but not daughters have rights by birth. A gain while three of the southern states (Andhra Pradesh, Tamil Nadu, Karnataka) and Maharashtra have amended this by including daughters as coparceners, and Kerala has abolished joint family property altogether, all the other states remain highly unequal. In the case of Muslim law, differential shares arise because daughters are allowed only half the share of sons in any property.

In both Hindu and Muslim legal systems the regional contrast is also striking. Gender inequality increases as we move from south India northward. Among Hindus, for instance, northwest India is the most gender unequal in relation to women's claims in both agricultural land and joint family property, while the southern states provide relative legal equality on both counts. Central India falls in-between. The map of women's legal rights under Muslim law looks rather similar, with a distinct contrast between northwest India and the rest of the country.

The enormity of women's disinheritance ( such as that noted in Chen's survey, with only 13 percent of daughters inheriting), however, cannot be explained by unequal laws alone. Rather, among the critical factors underlying both the law and the gap between law and practice are social and administrative biases.

\section{Social bias}

Consider first the gap between legal rights and actual ownership. In most communities that were traditionally patrilineal there is strong male resistance to endowing daughters with land. Apart from a reluctance to admit more claimants to the most valuable form of rural

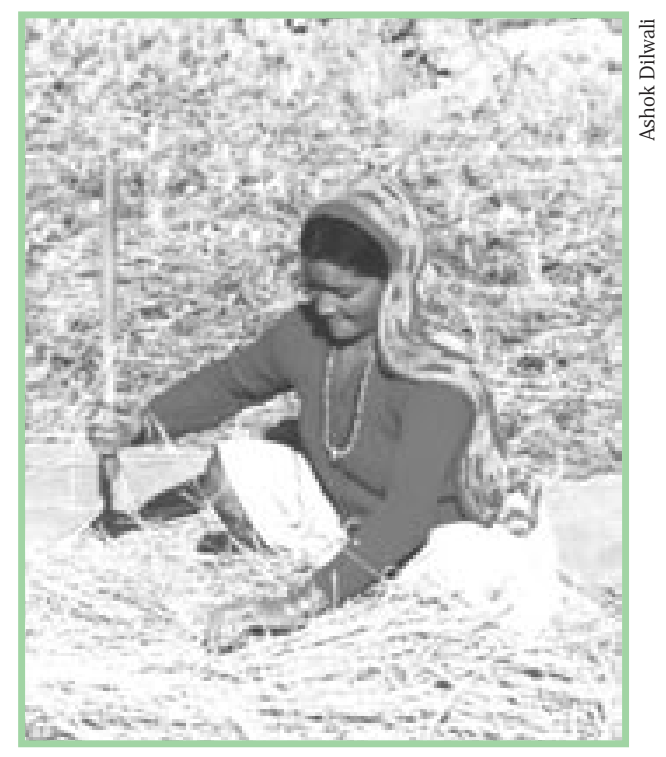

property, resistance also stems from social practices which determine marriage choices and postmarital residence. Traditionally among matrilineal communities where daughters had strong claims in land (as in Kerala and Meghalaya), postmarital residence was in or near the natal home. This kept the land under the overall purview of the natal family, as did close-kin marriage. In contrast, in traditionally patrilineal communities, post- 
marital residence was patrilocal (the woman joined her husband in his natal home) and often in another village. In addition, in northern India close-kin marriage was forbidden among most communities, and there were social taboos against parents asking married daughters for help during economic crises.

Many of these customs continue today, and obstruct women's claims especially among upper-caste Hindus of the northwest who are the strictest in forbidding in-village and close-kin marriages, and in socially restricting parents from seeking help from married daughters. Here endowing a daughter with land is seen as bringing virtually no reciprocal benefit, and any land inherited by her is seen as lost to the family. Daughters face the greatest opposition to their inheritance claims among such communities. Opposition is less in south and northeast India where in-village and close-kin marriages are allowed, and parents can, if they need to, seek support from married daughters.

Many women also forgo their shares in parental land in favor of brothers. In the absence of an effective state social security system, women see brothers as an important source of security, especially in case of marital breakup, even if in practice brothers are seldom willing to support sisters for extended periods. Cultural constructions of gender, such as how a "good sister" would behave, and practices such as female seclusion in some areas also discourage women from asserting their rights. Where women do not "voluntarily" forgo their inheritance claims, male relatives have been known to file court cases, forge wills, or resort to threats and even physical violence.

The gender gap between the ownership and effective control of land is as striking as that between law and practice. Here too social practices and notions of male entitlements play an important role. For instance, marriages in distant villages make direct cultivation by women difficult. In many areas this is compounded by illiteracy, high fertility, and social restrictions on women's mobility and public interaction. While the practice of veiling is geographically restricted, the ideology of female seclusion is more widespread and operates in complex ways. Effectively, it restricts women's contact with men by gendering forms of behavior, and gendering public and private space. Indeed in many north Indian villages, there are identifiable spaces where men congregate which women are expected to avoid, such as the market place.

This territorial gendering of space reduces a woman's mobility and participation in activities outside the home, especially market interaction; limits her knowledge of the physical environment; and disadvantages her in seeking information on new agricultural technologies and practices, in purchasing inputs, and in selling the product. These restrictions are strongest in northwest India (and especially in the plains) and virtually absent in the south and northeast. Of course, the cultural construction of gender, which defines appropriate female behavior, is not confined to northwest India; it also restricts women in southern India. But the strong ideology of purdah in the northwest circumscribes women in particular ways.

This regional difference in the social restrictions women face is also reflected in women's labor force participation rates, which are among the lowest in the northwest. Although this does not imply lesser workloads for women in aggregate terms, it does indicate lesser work mobility, lower economic visibility, and sometimes lesser exposure to the range of agricultural tasks.

Other difficulties facing women farmers include their limited control over 
cash and credit for purchasing inputs, gender biases in extension services, ritual taboos against women ploughing, and demands of advance cash payments by tractor or bullock owners for ploughing women's fields. (No such demand is usually made of male farmers, who, even if they are small owners, are assumed to be creditworthy.) Taboos against ploughing increase women's dependence on male help and reduce yields if ploughing is not done in time.

\section{Administrative bias}

Community- and family-related social constraints are compounded by the unhelpful approach of many government functionaries who typically share the prevailing social biases and often obstruct the implementation of laws favoring women. The bias is especially prevalent in the recording of daughters' inheritance shares by village officials. In the northwestern state of Rajasthan, for instance, a number of village officials told the author that although they encouraged widows

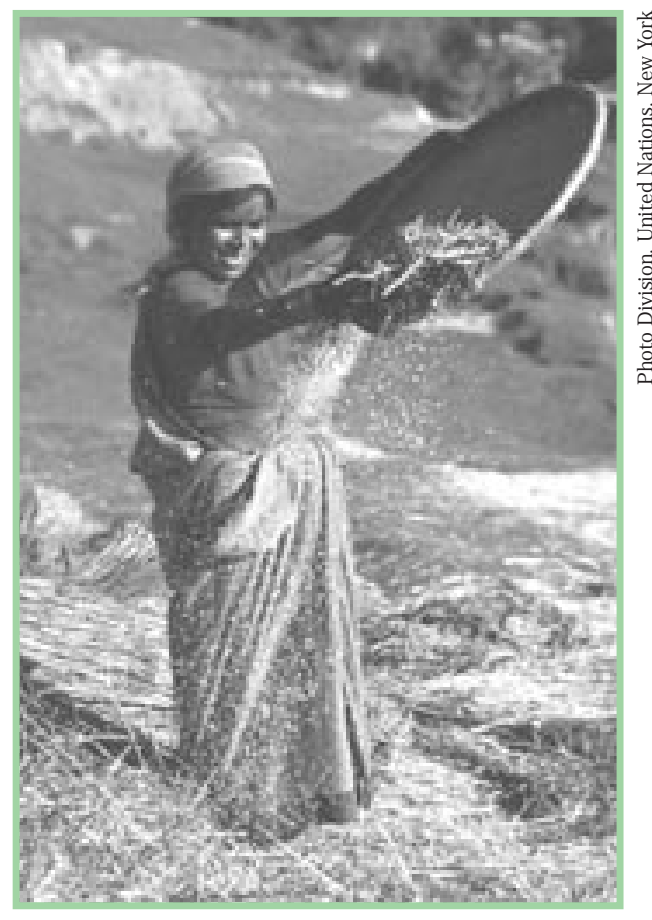

to claim their shares, they discouraged daughters from doing so. Village councils also tend to favor men on this count.

At one level, all these constraintslegal, social, and administrative-appear formidable. Yet, as noted throughout, there is a striking regional variability in the strength of the constraints (Agarwal 1994). This provides potential entry points for change. South India has the fewest obstacles. Here legal rights are relatively more equal, in-village and close-kin marriage is allowed, there is virtually no purdah, and female labor force participation is medium to high. Northwest India is the area of most difficulty on all these fronts. Northeast and central India come in-between. South India could thus provide an important starting point for furthering the goal of gender equality in effective property rights. Demonstrated achievements in one region could help subsequent attempts in other regions.

\section{Government Transfers}

While male bias within families can to some extent be explained in terms of conflicting interests and social attitudes in relation to private land, why do governments also transfer public land mostly to men? There appear to be several reasons for this bias.

To begin with, there is the common assumption that men are the primary cultivators and breadwinners and women are the helpers and dependents. There is also a widespread social perception regarding women's appropriate roles and capabilities. Here patrilineal biases have influenced even matrilineal communities. In Meghalaya, for instance, when government officials were asked by the author in 1989 why, even in a traditionally matrilineal society, they did not allot land to women, they responded: "Women can- 
not come to our office to fill out papers." Yet in nearby streets there were numerous women traders selling their wares.

More generally, land-related policy continues to be formulated largely on the assumption of a unitary household within which resources transferred to men are seen as benefiting the whole family. However, the substantial evidence of unequal intrafamily resource allocations, noted earlier, indicates otherwise. Interestingly those who most vociferously oppose such resource transfers to women often implicitly recognize that families are far from harmonious or altruistic institutions. Rather they fear that women will leave the family if they have the fallback option that property ownership would provide. For example, during the Constituent Assembly debate on the reform of inheritance and marriage laws suggested in the Hindu Code Bill in 1949, one Congress legislator from West Bengal argued: "[If the daughter inherits,] ultimately the family will break up" and queried: "Are you going to enact a code which will facilitate the breaking up of our households?" (GOI 1949: 1011). Forty years later, in 1989, following my presentation on gender and land rights at a land reform seminar at the Indian Planning Commission, the then Minister of Agriculture from northwest India exclaimed: "A re you suggesting that women should be given rights in land? What do women want? To break up the family?" Ironically, neither legislator need have feared this if indeed households were models of harmony and altruism, or if its members had the same interests and preferences.

A concern with family unity also limits the nature of transfers to women in the rare cases when such transfers do take place. For instance, there is a longstanding assumption in public policy that farms will be cultivated on a family basis. As a result, the emphasis has been mostly on giving women joint titles with hus- bands, and allotting titles to widows only in the absence of adult men in the family.

In fact, it is fallacious to assume that improving women's economic situation will lead to family break-up. The likelihood is that greater economic equality between men and women within the Indian family will help improve intrahousehold resource allocation and gender relations and strengthen family relationships. For instance, husbands will be less likely to desert or divorce wives who own property or have other means of access to assets such as land or homesteads.

\section{W hat Should Be Done?}

Given their entrenched nature, how can the noted obstacles to women's land rights be overcome? To enhance gender equality in land and livelihoods, changes appear necessary on at least five counts: conceptual, legal, social, institutional, and infrastructural ( see Box 3).

\section{Conceptual and Empirical}

For a start, it appears necessary to challenge the conventional model of a harmonious male-headed family in analysis as well as policy, and to recognize the family for what it is: a unit of both cooperation and conflict, of both sharing and selfishness, where women and men can have different interests, preferences, and motivations, where self-interest also enters, and where allocations are often unequal and affected by differential bargaining power. Indeed, there is an emerging consensus among genderaware economists about the validity of the bargaining approach to understanding intrahousehold dynamics. But ideologically the unitary household model holds strong. If we are to think of radical and effective interventions, it appears critical to shift to more realistic assumptions about intrafamily behavior when formulating policy. 


\section{Box 3}

\section{What Needs to Be Done?}

\section{For Improving Women's Claims in Private Land}

1. Gender equality in inheritance laws

2. Legal literacy and legal support services

3. Village-level recording of women's shares

4. Social and economic support for women from outside the family, including through an effective social security system

5. Changing social attitudes

\section{For Improving Women's Access to Public Land}

Gender equality in public land distribution in:

1. Land reform schemes

2. Resettlement schemes

3 Other schemes, such as those initiated under poverty-alleviation programs

\section{For Improving Women's Access to Land Via the Market}

1. Subsidized credit for land purchase or lease

2. Land purchase or lease via group formation, and group cultivation of such land

\section{For Improving the Viability of Women's Farming Efforts}

1. Agricultural extension services and other infrastructural support for women farmers

2. Resource pooling and group investment in capital equipment; cooperative marketing

3. Women's effective presence in village decisionmaking bodies

4. Gender sensitizing through the media, educational institutions, etc., for changing social norms and social perceptions.

It is also important to gather systematic gender-disaggregated information on land ownership and use, both for bet- ter understanding the existing situation and for effective monitoring. The Agricultural Census of India and the National Sample Surveys (NSS), which both carry out periodic data collection on land ownership and use, collect only householdlevel information. There is a case here for incorporating, in the next NSS round, a special module of questions for obtaining gender-disaggregated intrahousehold information. If necessary, this could initially be tried on a pilot basis, and subsequently extended to the full survey. Nepal, as noted, has already redesigned its census to gather such information. Researchers collecting land-related data in other projects could also be encouraged to collect gender-disaggregated information on land ownership and use.

\section{Legal}

The legal aspects should include at least three elements.

Amending the inheritance laws: These would include a number of changes, such as bringing agricultural land on par with other forms of property in the laws applicable to Hindus as well as those applicable to Muslims; abolishing the joint family property provision in the HSA, as done in Kerala; and so on. Even though legal changes are not a sufficient condition for ensuring women's ownership and control over property, legal equality provides an essential tool in the hands of gender-progressive groups, who could then work for de facto equality. Progressive legislation also underlines the State's commitment to the idea of gender equality.

Legal literacy: This is essential to make laws effective and needs to reach both adults and near-adults. For the latter, legal literacy could be made part of the curriculum in the senior years of school.

Recording women's shares: Village women need support to ensure that their land shares are correctly recorded by the relevant village official, and need legal 
advice and help if they wish to contest their claims with either the family or the administration.

In all these efforts, gender-progressive groups could play a significant role.

\section{Social}

Unless and until women's claims begin to be seen as socially legitimate, parents who have a male bias are likely to use the right of making wills to disinherit daughters, even if the laws are made fully gender-equal. Similarly, efforts are needed to change conservative or negative perceptions about women's appropriate roles and abilities, and to challenge social norms that restrict women's public mobility and interaction.

For instance, the problem posed by women's marriage outside the natal village arises only partly from the distances involved and mostly from social strictures on women's mobility, and social perceptions about women's lesser abilities and deservedness. Men are seldom denied their property rights even if they migrate to distant parts (as many men, especially younger ones, do to seek jobs in cities).

Although social attitudes, norms, and perceptions are not easy to alter, certain types of interventions could further the process. For instance, government initiatives to transfer land titles and infrastructural support to women farmers would have a notable demonstration effect. Interventions to strengthen extrafamily economic support for women, including through a government social security scheme, would help reduce women's dependence on relatives and especially on brothers in whose favor women often forgo their claims. Overall, economic support would also enhance women's ability to challenge inequalities in the family and community. In so far as the popular media is one of the arenas where gender roles and relations are both projected and constructed, media interventions in a gender-progressive direction would also help transform social attitudes.

\section{Institutional}

Reforms in this area need to be holistic and innovative. For instance, policymakers generally assume that farms will be cultivated on a family basis. Hence to the extent that the government is beginning to recognize that women farmers too have legitimate claims in land, joint titles (titles held jointly by husbands and wives) are mostly favored. Such titles have both positive and negative implications. On the positive side, clearly getting some land is better for women than having none. But on the negative side, joint titles also present women with several potential problems. Women often find it difficult to gain control over the produce, or to bequeath the land as they want, or to claim their shares in case of marital conflict. As some rural women explained: "By being tied to the land we would be tied to the man, even if he beat us" (author's interviews, 1989). Also with joint titles wives cannot easily exercise their priorities in land use if these priorities happen to differ from those of their husbands. Most importantly, joint titles constrain women from exploring alternative institutional arrangements for cultivation and management.

Individual titles, by contrast, give women greater flexibility and control over the land. At the same time, individual women often lack funds for equipment or inputs, and where holdings are very small individual investment in equipment can prove uneconomical. Individual women also face considerable pressure from male relatives who want to acquire or control the land.

However, institutional solutions to these problems can be found, provided women's land claims are not tied to their spouses, and if the unit of investment and cultivation is not limited to the 
Table 2 W omen Managing Land Under Various Institutional Arrangements

\begin{tabular}{|c|c|c|c|c|c|}
\hline Form of control & Source of land & Investment & Cultivation & Use & $\begin{array}{l}\text { Examples of actual } \\
\text { practice }\end{array}$ \\
\hline \multicolumn{6}{|l|}{ Conventional approach } \\
\hline Individual women & Inherited or purchased & Individual & Individual & Crops & Typical \\
\hline \multicolumn{6}{|l|}{ Alternatives } \\
\hline $\begin{array}{l}\text { 1. Individual } \\
\text { women }\end{array}$ & $\begin{array}{l}\text { Inherited, purchased, } \\
\text { or government transfer }\end{array}$ & $\begin{array}{l}\text { J oint (with } \\
\text { other women) }\end{array}$ & Individual & Crops & $\begin{array}{l}\text { Bodhgaya (Bihar) } \\
\text { (government promoted) }\end{array}$ \\
\hline $\begin{array}{l}\text { 2. Individual ownership, } \\
\text { group management } \\
\text { by women }\end{array}$ & $\begin{array}{l}\text { Group purchase of } \\
\text { private land by women, } \\
\text { divided into individually } \\
\text { owned plots }\end{array}$ & $\begin{array}{l}\text { J oint (with } \\
\text { other women) }\end{array}$ & J oint & Crops & $\begin{array}{l}\text { Deccan Development } \\
\text { Society (DDS) in } \\
\text { Andhra Pradesh }\end{array}$ \\
\hline $\begin{array}{l}\text { 3. Group of } \\
\text { women }\end{array}$ & $\begin{array}{l}\text { Group lease of private } \\
\text { land }\end{array}$ & J oint & J oint & $\begin{array}{l}\text { Crops } \\
\text { Vegetables }\end{array}$ & $\begin{array}{l}\text { DDS, BRAC } \\
\text { Kerala }\end{array}$ \\
\hline $\begin{array}{l}\text { 4. Group of } \\
\text { women }\end{array}$ & $\begin{array}{l}\text { Male owners; cultivation } \\
\text { overseen by women's } \\
\text { groups }\end{array}$ & Individual & Individual & Crops & $\begin{array}{l}\text { DDS's Community } \\
\text { Grain Fund Scheme }\end{array}$ \\
\hline $\begin{array}{l}\text { 5. Group of } \\
\text { women }\end{array}$ & $\begin{array}{l}\text { Government transfer } \\
\text { to women's groups }\end{array}$ & J oint & J oint & Crops & Untried so far \\
\hline
\end{tabular}

household, indeed is not defined by the household at all. Table 2 summarizes these alternatives.

One alternative would be to help women who own individual holdings (whether obtained through inheritance, purchase, or from the government) to invest in capital inputs jointly with other women, while managing production individually. Male farmers have done this in several regions, by jointly investing, say, in a tubewell where they have contiguous plots. This reduces the individual cost of major investments. Women owners of plots could be encouraged to do the same. In fact, in Bodhgaya, a government scheme provided funds to groups of five farmers each to invest in pumpsets. Two such groups were constituted of women farmers alone. Although there are no follow-up reports on how well this worked, it was a step in the right direction.

A second type of arrangement could be for women to purchase land jointly while owning it individually and farming it collectively. One of the most interesting examples of this is the Deccan Development Society (DDS), an NGO working with poor women's collectives in some 75 villages in Medak district-a drought-prone tract of Andhra Pradesh (AP) in southern India. DDS has helped women from landless families establish claims on land, through purchase and lease, using various government schemes (for a detailed discussion, see Menon 1996; Satheesh 1997; and Agarwal 2001).

One such scheme of the Scheduled Caste Development Corporation in AP provides subsidized loans to landless scheduled caste women for buying agricultural land. Catalyzed by DDS, women form a group, apply for the loan after identifying the land they want to buy, and divide the purchased land among themselves, each woman being registered as the owner of about an acre. Cultivation, however, is done jointly by each group. Today 24 women's groups in 14 villages are jointly cultivating 474 acres of purchased land. In the process of working together, they have learned to survey and measure land, hire tractors, travel to distant towns to meet government officials, obtain inputs, and market the produce. Moreover, DDS has systematically promoted organic farming in all its crop cultivation schemes. Women also grow a combination of crops ( rather than a single crop), which reduces the risk of 
total crop failure and provides a more balanced diet.

J oint purchase and cultivation of land by women's groups could now be encouraged in other states as well, on the basis of other government schemes. For instance, a 1995-96 central government scheme in India provides loans to the poor for land purchase as part of the Integrated Rural Development Programme.

A third possibility lies in women leasing land as a group and cultivating it jointly. Under one of DDS's programs, women in AP lease in land from private owners. Initiated in 1989, the program is now said to cover 623 acres across 52 villages. Under another of DDS's efforts, women's groups have used loan money available via the government's poverty alleviation scheme, DWACRA (Development of Women and Children in Rural Areas), for leasing in land. Committees of women examine the lease proposals, assess land quality, keep records of each woman's work input, and ensure equitable distribution of wages and produce. Women who fail to turn up for collective labor are subject to fines (such as two days' wage equivalent) decided by the women in their weekly group meeting. Persistent default can lead to exclusion from the group (author's interviews, September 1998). Several women's groups have used the revolving fund provided under this scheme to collectively lease in and cultivate land. An assessment in 1995 showed that each woman participant received enough cereal and pulses to feed the whole family for a month, in addition to receiving harvest wages. DWACRA loans have seldom been used in such innovative ways.

DDS is not the only NGO encouraging land leasing by women's groups. In Kerala, some women's groups are leasing land during the off-season for vegetable cultivation. In Bangladesh, women's groups belonging to the Bangladesh Ru- ral Advancement Committee (BRAC) grow crops on leased-in land.

A fourth type of institutional arrangement is of women's groups managing and overseeing cultivation on land owned by men. Again DDS provides an illustrative example. Here women are jointly overseeing the cultivation of privately owned land that had been lying mostly fallow. Most of this was ceiling surplus land of poor quality distributed by the government to landless men. The land remained largely uncultivated, while the families depended heavily on the public distribution system (PDS), which was woefully inadequate for providing food security. Supported by the Ministry of Rural Development, DDS initiated this program to bring fallow land under the plough, by extending subsidized loans to the owners. Under the scheme, each participating farmer can enter two acres, and get loans in installments over three years. In return, over five years, the farmer gives a specified percentage of the grain he harvests to a Community Grain F und ( CGF ). Committees of women make sure that the farmers use the loans for cultivation and collect the harvest share for the CGF. This grain is sold at a low price to the poorest households in each village. The CGF thus serves as a form of alternative PDS. This project is now working in 43 villages, covering 3,263 acres and 2,247 marginal and small farmers, and is estimated to have produced enough extra grain to provide 3 million total extra meals or 1,000 extra meals per family.

A fifth type of arrangement, untried to date, is one where poor rural women could hold group rights over land distributed by the government, or otherwise acquired by women (Agarwal 1994). Effectively, the women would be stakeholders in a kind of land trust. Each woman in the group would have use rights but not the right to alienate the land. The daughters-in-law and daughters of such 


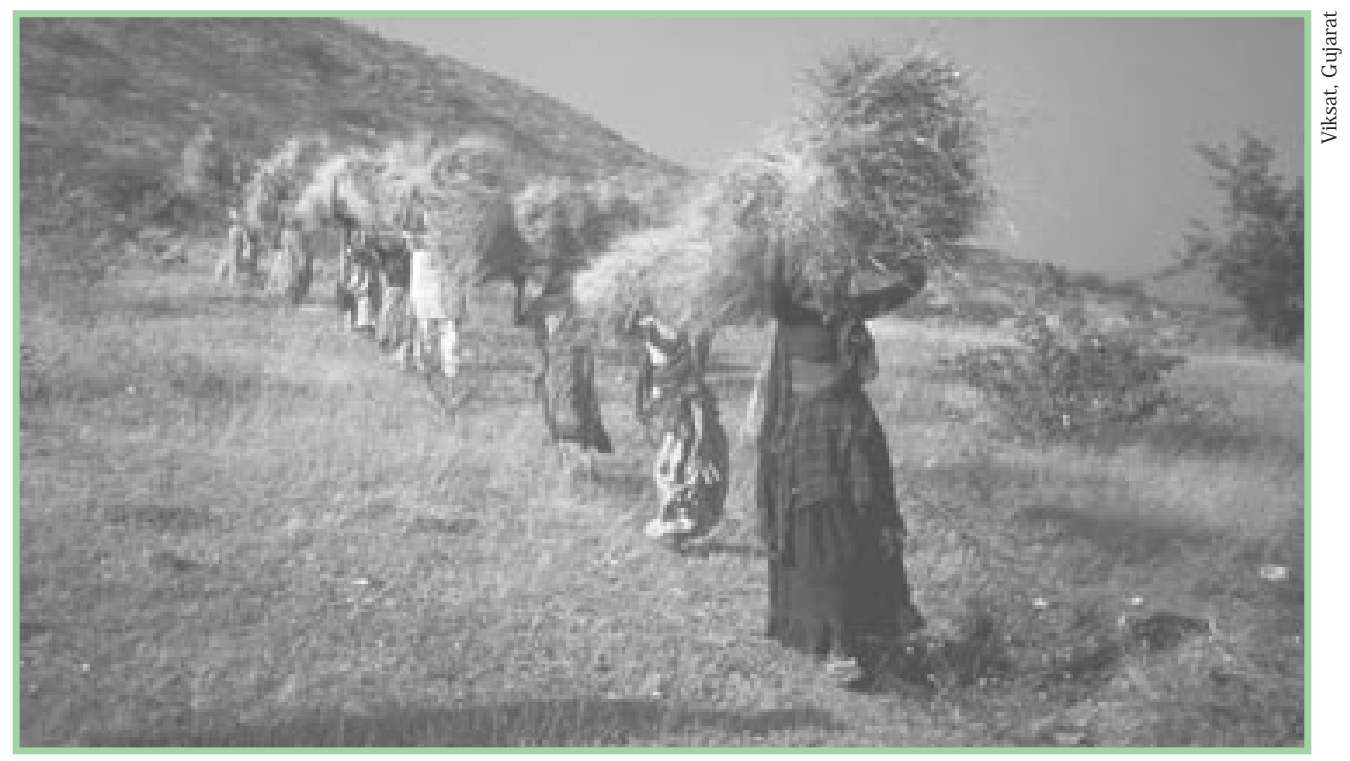

households who are resident in the village would share these use rights. Daughters leaving the village on marriage would lose such rights but could re-establish them by rejoining the production efforts, should they return, say on divorce or widowhood. In other words, land access would be linked formally with residence and working on the land, as was the case under some traditional systems when land was held collectively by a clan.

In these various institutional alternatives, women are not just adjunct workers on family farms; they have direct control over production and distribution. Cooperation is between women with common interests, and not between households. The arrangements enable women to gain access to land through the market or through the community-access that women rarely have as individuals. Where linked with land pooling, joint investment, and collective management, these arrangements can also help overcome any problems of small size and fragmentation.

Moreover, a collective approach to land management helps women mobilize funds for capital investment on the farm, take advantage of economies of scale, and cooperate in labor sharing and product marketing. In addition, if the land is held under a system of group rights (as in the fifth alternative) it would strengthen women's ability to withstand pressure from relatives and retain control over the land; and it would circumvent the problem of inheritance, since the women would not have rights of alienation ( see Box 4). It would also circumvent the issue of outside-village marriages, since women's rights would be based on residence. In 1995, when the author asked a number of women elected to village panchayats in Madhya Pradesh which arrangement they felt might be of most advantage to women-individual titles, joint titles with husbands, or group rights with other women-most strongly supported the idea of group rights (Madhya Pradesh Chief Minister's consultation meeting in 1995 on the state's proposed Policy for Women).

Some policymakers and scholars argue against cooperative farming by pointing to India's failed efforts of the 1950s and early 1960s. However, the focus then was on households, and on male heads as 
Box 4

\section{The Deccan Development Society: Impact of Women Acquiring Land and Farming Collectively}

The following quotes capture the changes women have experienced:

Our husbands used to drink and beat us. Now the buffaloes are ours, the land is ours and they are working too. Nobody is taking advantage of us women. (Ratnamma, Algole village, cited in Hall 1999)

Now [with land] we have the courage and confidence to come out and deal with people and property by ourselves. (Chilkamma, K rishnapur village, cited in Hall 1999)

Now we are self-sufficient. [We are] able to get food and clothing.... Pre viously we had nothing and had to say yes to everything; now we have status because we have the land. ( Pastapur women's group, cited in Hall 1999)

Initially the men said: If women go to meetings, what should we men dowash the dishes? We said, men and women should work equally... Are we the only persons born to work? Earlier we ate half a roti, now we eat one. (Sharifabi to author 1998)

[With group cultivation] women can share the profit and the responsibility. In individual cultivation, different women have different levels of agricultural knowledge and re sources for inputs. In collective cultivation they can make unequal contributions. Those with less can compensate the others by taking a re duced share of the harvest, or by repaying them in installments. Differ- ent levels of contri bution are fine, because the women all know what each other's resources are. (Chinanarsamma, Pastapur village, cited in Hall 1999)

They [the high-caste people] used to call us with the caste name which was very derogatory. They would also call us in the singular form. Now they put the motherly [respectful] suffix and gi ve us equal seats.... It is only because we have an organization that they [the landlords] won't touch us-that they arescared to cross us. (Ratnamma, Algole village, cited in Hall 1999)

[We] found that during the course of meeting, we became a kind of mutual support group. If any woman fell ill or had a problem, the others would try and help. So it became a habit to meet, and we were not afraid of family di sapproval. Gradually the fami ly realized the importance of our meetings to us and fell silent. (Single women's group to author, 1998)

The first sense of empowerment came to women and men in the community when the women started leasing in land. Men, and especially powerful men in the villages, had the percepti on that women were useless, that as agricultural labourers they could only work under supervision. This perception was slightly internalized by the women. The land leases completely debunked this vi ew. (P.V. Satheesh, Director of DDS, cited in Hall 1999) representatives of households. Not only did gender receive no mention, but inadequate attention was paid also to socioeconomic inequalities between households, with the result that cooperatives were often large-farmer dominated. A crucial difference in the approaches outlined here is that the institutional forms discussed shift the focus of cooperative efforts from disparate village households to disadvantaged individuals with common interests. Focusing on the effects on poor women could open an important window of opportunity to revive land reform, community cooperation, and joint farming in a radically new form.

For trying out some of these institutional arrangements the southern states 
could be starting points, since here both laws and the social context (as noted) are relatively less gender-biased than in the northern states.

\section{Infrastructural}

The success of women's farming efforts, whether as individuals or groups, can depend crucially on their access to infrastructure. As noted earlier, there are significant gender (in addition to class) inequalities in access to credit, labor, other production inputs (including hired equipment), and information on new agricultural technologies. Poor women cultivating very small plots have the most difficult time in this regard.

Prevailing gender biases in the delivery of government infrastructure thus need to be removed. To some degree, this could be done by employing more women in agricultural input and information delivery systems (women extension agents are often recommended for this purpose), but such systems also need a reorientation of male functionaries so that they too contact and assist women farmers.

Also, dependence on the State alone may not be enough, or have the same potential for success in reaching women as nongovernmental initiatives. For instance, in credit delivery to poor women, NGOs such as the Grameen Bank in Bangladesh and the Self Employed Women's Association (SEWA) in India have been more successful than government agencies. The role of NGOs could similarly be important in providing technical information, production inputs, and marketing facilities to groups of women farmers. $B R A C$ in Bangladesh is a case in point: although it does not focus only on women, it provides a range of relevant informational, technical, and market support services to its members. A systematic promotion of women's cooperatives for production inputs and marketing could also be considered.

\section{Collective Action}

If today... [they] who fought for the Independence of India are to be denied their just rights, then our hard-earned freedom is no more than a handful of dust.

- Padmaja Naidu, Congress Legislator (Parliamentary debates over the Hindu Code Bill, 1951)

For initiating and sustaining the complexity of changes required to strengthen women's land claims in India, the committed involvement of a range of actors, and especially of a wide spectrum of women, will be necessary. It will require various forms of collective action by women, both in relation to State policy and its implementation, and in relation to land access via the market, the community, and the family. Such collective action should also seek to bring into its fold gender-progressive elements (men and women) within the State, political parties, and civil society groups.

After over two decades of the women's movement in India, many now recognize the importance of collective action. But much of the effort to enhance women's economic empowerment has been concentrated on issues other than land (or property), such as better wages, group credit schemes, micro-enterprise development, and so on. Group action is now needed for women to gain access to land, in recognition of its central importance in most rural women's livelihoods, whether as the primary or a supplementary income source.

The local bureaucracy would be more likely to register individual women's claims in family land if there were collective pressure from gender-progressive groups. Such organizations could also provide women with vital information about the laws and legal support, if necessary. In fact, a woman's group in the Santal Parganas is providing both legal support and financial help to women who wish to contest their claims (personal 
communication from social activist Nitya Rao, Bombay, 1997). Similarly, SEWA in Gujarat gives women loans to help them register their names as joint owners in their husbands' land (personal communication, Renana J habvala, 1997).

Gender-progressive organizations could also strengthen women's bargaining position through economic and social support structures that reduce women's dependence on male relatives, especially their brothers in whose favor women often forfeit their claims As a woman member of BRAC tellingly asserted: "Well the organization is [now] my "brother'" (Hunt 1983: 38). Such organizations could also help women demand that the government put in place a well-structured social security system.

Equally, a collective challenge by women can facilitate some change in restrictive social norms. Even female seclusion practices can be subject to change through group challenge. In fact women's attempts to collectively challenge purdah go back a long way. In India in the 1920s and 1930s, for instance, many individuals and organizations, both Hindu and Muslim, highlighted the burden and constraints imposed on women by purdah; and resolutions against the practice were also passed by a number of groups. In the city of Calcutta, an anti-purdah day became an annual event in the 1930s, organized by the Hindu Marwari business community (which prescribed strict purdah). In 1940, some 5,000 women attended an anti-purdah conference. The woman president of the conference arrived in a car driven through the city by a Marwari woman, followed by a procession of Marwari women on foot led by girls riding on horseback (Forbes 1981)!

Today the challenge to purdah continues both in India and in other parts of South Asia. In Bangladesh, for instance, while economic exigency has created the need to challenge purdah, group solidarity has strengthened women's ability to sustain the challenge. As a women's group organized by BRAC noted in the 1980s:

They said... [we] are ruining the prestige of the village and breaking purdah.... Now nobody talks ill of us. They say: "They have formed a group and now they earn money, it is good." ( cited in Chen 1983: 177, 165)

In fact, the experiences of the Grameen Bank, BRAC, SEWA, and many other NGOs working with poor women, using a group approach, suggest that some restrictive social norms could be challenged successfully as a by-product of forming groups for the more effective delivery of economic programs.

Group support for village women can be provided both by separately constituted groups which give women specialized help, and by organizations comprised of village women themselves. The presence of more women in the village panchayats, as a result of the one-third reservation for women provided by the 73rd Constitutional Amendment in India in 1992, can also strengthen rural women's hands. Although simply having more women in such bodies cannot guarantee gender-progressive programs, the record of elected all-women village panchayats preceding the Amendment, as in Maharashtra and Madhya Pradesh, leaves room for optimism: women in these bodies were found to be more sensitive to women's concerns and to give priority to their needs in ways that male panchayat members typically did not (Gandhi and Shah 1991). Women's presence in positions of authority also has a favorable demonstration effect and can change social attitudes and perceptions about women's roles. Moreover, village women are more likely to take their grievances to women representatives than to allmale bodies.

However, support for women's land claims on a large scale, and beyond localized experiments, will need much more broad-based collective action by 
women. For building such cooperation, economic and social differences between women might prove to be obstacles on certain counts. But there are still significant areas of mutual benefit that cut across class/caste lines, around which successful cooperation would be possible, and which could serve as starting points. One is legal reform. Women of both rich and poor peasant households with a stake in family land stand to gain from gender-equal inheritance laws. Many people mistakenly assume that the percentage of such women is small. In fact it is substantial: despite the highly skewed distribution of land, some 89 percent of rural Indian households own some land, even if most own only small plots. E qually, challenging restrictive social norms will bring benefits for women of both well-off and poor households.

The experience of the women's movement in India also indicates that women of different socioeconomic backgrounds can cooperate strategically for legal reform, as they did in campaigns to amend dowry and rape laws, despite differences in ideologies, agendas, and social composition. Moreover, many urban middleclass women activists have played and continue to play important roles in promoting poor rural women's economic and social concerns, such as supporting their campaigns for higher wages, and their programs for wasteland management, credit, and small-enterprise development. In more recent years, there have been also some significant cases of middleclass activists promoting poor women's land claims, as in the Bodhgaya movement in Bihar, the Shetkari Sanghatana in Maharashtra, and the DDS in Andhra Pradesh. These experiences again indicate that cooperation between women, which cuts across economic and social heterogeneity, is possible on a number of issues and in varied contexts.

All said, there now appears to be a favorable climate for raising the question of women's independent claims to land and livelihood, and it is imperative to do so, given the noted importance of land in women's lives. Some NGOs which earlier concentrated on other issues are now beginning to focus on women's property issues, including agricultural land and homestead plots in rural areas, and dwelling houses in urban areas. Cases in point are SEWA in Gujarat, Action India in Delhi, and the Association for Land Reform and Development in Bangladesh. Several grassroots groups and development organizations in South Asia have held workshops on the question of women and land in recent years. In Nepal a movement has been ongoing for several years spearheaded by feminist lawyers for reforming gender-unequal inheritance laws. A number of South Asian women's groups also have been arguing for gender equality in inheritance laws by emphasizing that their constitutions promise equal treatment of women and men. Moreover, women's groups that have not raised the issue of women's land and property claims directly have still, over the years, spread an awareness of gender concerns. This has created an environment within which women's claims to land can be placed more centrally in the arena of public concerns-something that was not easy to do twenty years ago.

A window of opportunity is also provided by the growing attention being given to watershed development and localized irrigation schemes by a number of NGOs and some government agencies, in several parts of South Asia. But once land becomes more valuable with the availability of irrigation, women's land claims are unlikely to be recognized. The opportune time to establish women's claims is during the process of developing the watershed or irrigation facility, not afterward.

Moreover, as noted, there needs to be a shift away from the overwhelming pre- 
occupation of most rural NGOs, donor agencies, and governments with microcredit delivery toward the creation of productive assets, especially landed assets, in women's own hands, and toward enhancing women's capacities as farmers. In this context, women's rights in arable land and homesteads need to become a central part of the development discourse. Here development agencies that fund research or grassroots action could also play a significant positive role.

In seeking change, the aforementioned regional variations in women's social position and hence in the extent of opposition to women's land claims could be put to useful effect, for instance by initially building a momentum for change in regions of less opposition ( such as in the southern states of India), and then working for change in the more resistant regions.

Finally, given that this issue is significant and relevant for women in many countries, there is scope here for sharing experiences and strategies for change; for building horizontal linkages between groups with similar goals; and for international coalitions both between South Asian countries and between South Asia and other parts of the globe. This would be facilitated by emerging international support for women's claims in property. The Convention on the Elimination of All Forms of Discrimination Against Women (CEDAW) has focused on equality in property as one of its important directives. The United Nations Conference on Human Settlements at its Istanbul meeting in 1996 also focused centrally on women and land. Since then the Huairou Commission in conjunction with the UNDP, Habitat, WEDO, and the Women's Caucus of the UN Commission on Sustainable Development has held several discussions with women's groups worldwide, to examine regional progress in enhancing women's access to land and property. The Huairou Commission is also requesting support for a global campaign to promote women's claims in land and property, and in housing rights for the urban poor under the auspices of the United Nations Center for Human Settlements.

All these national, regional, and international efforts that are beginning to emerge suggest that today the climate is certainly more favorable than it was two decades ago, for responding positively to the concerns raised by poor women in West Bengal: "Why don't we get a title? Are we not peasants?"

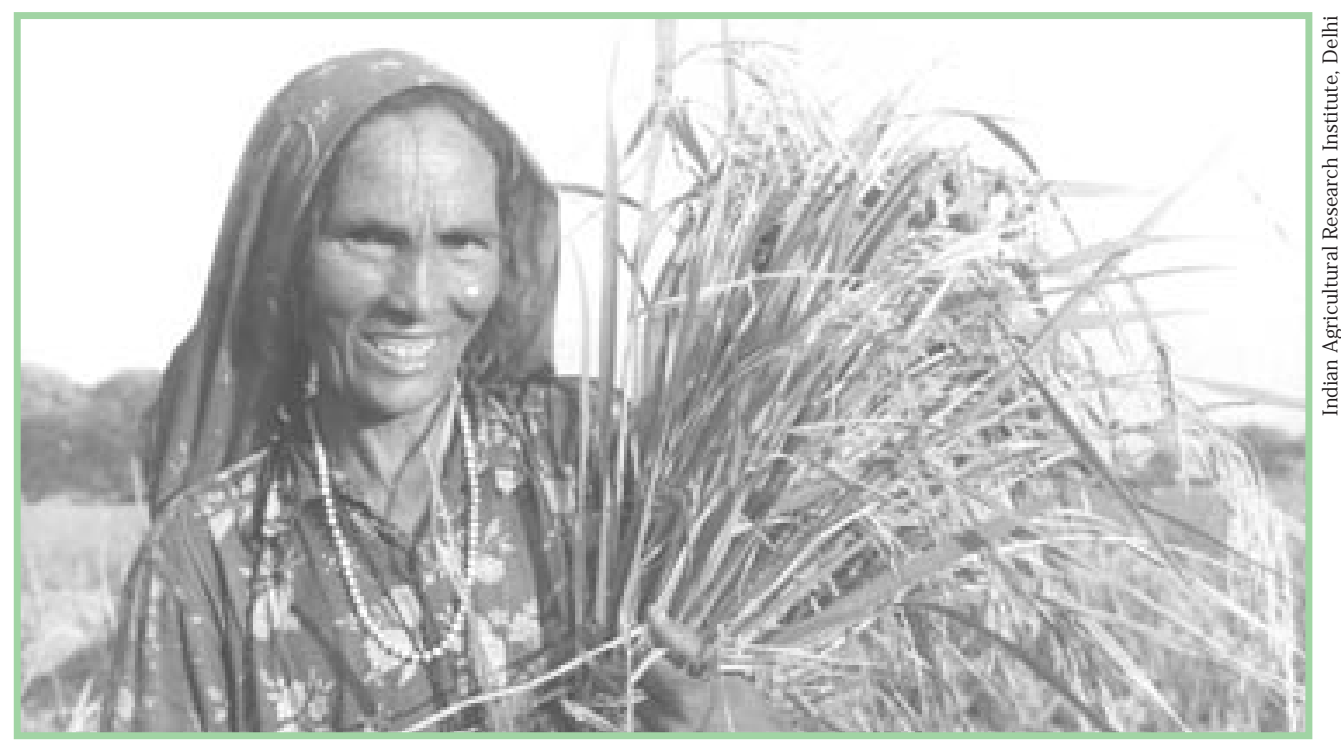




\section{References}

Agarwal, B. (1994) : A Field of One's Own: Gender and Land Rights in South Asia (Cambridge: Cambridge University Press).

Agarwal, B. (1995): “Women's Legal Rights in Agricultural Land," Economic and Political Weekly, Bombay, Review of Agriculture, March.

Agarwal, B. (2001): "Gender and Land Revisited: Exploring New Prospects via the State, Family and Market," paper written for the UNRISD conference on Agrarian Reform, Geneva, November.

Alaka and Chetna (1987): "When Women Get Land A Report from Bodhgaya," Manushi 40: 25-26.

Banerjee, A. (2000): "Land Reform: Prospects and Strategies," mimeo, Department of E conomics, Massachusetts Institute of Technology, Cambridge, $\mathrm{MA}$.

Caldwell, J . C., P. H. Reddy, and P. Caldwell (1988): The Causes of Demographi c Change: Experimental Research in South India (Madison: University of Wisconsin Press).

Chadha, G. K. ( 1992): “Non-farm Sector in India's Rural Economy: Policy, Performance and Growth Prospects," mimeo, Centre for Regional Development, J awaharlal Nehru University, Delhi.

Chakravartty, R. (1980): Communists in Indian Women's Movements: 1940-1950 (New Delhi: People's Publishing House).

Chen, M. A. (1983): A Quiet Revolution: Women in Transition in Rural Bangladesh (Cambridge: Schenkman Publishing Co.) .

Chen, M. (2000): Perpetual Mourning: Widowhood in Rural India (Philadelphia: University of Pennsylvania Press)

Cooper, Adrienne. (1988): Sharecropping and Sharecroppers' Struggles in Bengal 19301950 (Calcutta: K. P. Bagchi \& Company).

Custers, Peter. (1987): Women in the Tebhaga Uprising: Rural Poor Women and Revoluti onary Leadership 1946-47 (Calcutta: Naya Prokash).

Duraisamy, P. (1992): “Gender, Intrafamily Allocations of Resources and Child Schooling in South India," Economic Growth Center Discussion Paper No. 667, New Haven, CT: Yale University.

Dwyer, D. and J. Bruce (eds.) (1988): A Home Divided: Women and Income in theThird World (Stanford: Stanford University Press).

Elson, D. (1995): "Gender Awareness in Modeling Structural Adjustment," World Development 23 (11) : 1851-1868.

Forbes, G. (1981): “The Indian Women's Movement: A Struggle for Women's Rights or National Liberation?" in G. Minault (ed.), The Extended Family: Women and Political Participation in India and Pakistan (Columbia, MO: South Asia Books), pp. 49-82.

Gandhi, N. and N. Shah (1991): The Issues at Stake: Theory and Practicein the Contemporary Women's Movement in India (Delhi: Kali for Women).

Government of India (GOI) (1949): Constituent Assembly of India (Legislative) Debates, II, Part 2, Debate on the Hindu Code Bill, 25 February, 1 March.
Gupta, J. ( 1993): “Land, Dowry, Labour: Women in the Changing Economy of Midnapur," Social Scientist 21 (9-11): 74-90.

Hall, R. (1999): "Alternative Means by Which Women Have Acquired Land: An Indian Case Study," draft mimeo, Institute of Economic Growth, Delhi.

Hunt, H. I. ( 1983): "Intervention and Change in the Lives of Rural Poor Women in Bangladesh: A Discussion Paper," Bangladesh Rural Advancement Committee (Dhaka).

IFAD (2001): Assessment of Rural Poverty in Asia and the Pacific Region: Draft Final Report, International Fund for Agricultural Development, Asia and the Pacific Division.

Kumar, S. K. (1978): "Role of the Household Economy in Child Nutrition at Low Incomes," Occasional Paper No. 95, Dept. of Agricultural Economics, Cornell University.

Manimala (1983): "Zameen Kenkar? J ote Onkar! Women's Participation in the Bodhgaya Land Struggle," Manushi 14: 2-16.

Meer, S. (ed.) (1997): Women, Land and Authority: Perspectives from South Africa (UK and Ireland: Oxfam)

Menon, G. (1996): "Re-negotiating Gender: Enabling Women to Claim Their Right to Land Resources," paper presented at the NGO Forum of the UN Conference on Human Settlements-Habitat II, Istanbul, J une.

Quisumbing, A. (1996): “Male-Female Differences in Agricultural Productivity: Methodological Issues and Empirical Evidence," World Development 24 (10): 1579-1595.

Rahman, O. M. and J. Menken (1990): "The Impact of Marital Status and Living Arrangements on Old Age Female Mortality in Rural Bangladesh," Paper No. 1, Dept. of E pidemiology, Harvard School of Public Health, and Population Studies Center, University of Pennsylvania.

Rosenzweig, M. R. and K. I. Wolpin (1985): "Specific Experience, Household Structure, and Intergenerational Transfers: Farm Family Land and Labor Arrangements in Developing Countries," Quarterly J ournal of Economics 100, Supplement: 961-987.

Satheesh, P. V. (1997): "History in the Making: Women Design and Manage an Alternative Public Distribution System," Forests, Trees and People, Newsletter No. 34, September.

Shankar, K. (1990): Land Transfers: A Case Study (Delhi: Gian Publishing House).

Thomas, D. (1990): "Intra-household Resource Allocation: An Inferential Approach," J ournal of Human Resources 25 (4): 635-663.

Udry, C., J. Hoddinott, H. Alderman, and L. Haddad (1995): "Gender Differentials in Farm Productivity: Implications for Household Efficiency and Agricultural Policy," Food Policy 20 (5) : 407-423.

Verdery, K. (1996): What Was Socialism, and What Comes Next? (Princeton, NJ : Princeton University Press). 


\section{SEEDS Advisory Committee}

Judith Bruce (Population Council)

Marty Chen (Harvard University)

Monique Cohen (USAID)

Caren Grown (International Center for Research on Women)

Ann Leonard (Consultant)

J oyce Malombe (New Hampshire College)

Katharine McKee (USAID)

Aruna Rao (Consultant)

Mildred Warner (Cornell University)

Corinne Whitaker (International Women's Health Coalition)

Editor: Sandy Schilen

Editorial and Production Coordinator: Monica Rocha

Designer: Mike Vosika

Cover Photo: Preeti Schaden

\section{Other Editions of SEEDS Currently Available}

No. 2 Hanover Street: An Experiment to Train Women in Welding and Carpentry-J amaica (English, Spanish)

No. 3 Market Women's Cooperatives: Giving Women Credit-Nicaragua (Spanish, French)

No. 4 Women and Handicrafts: Myth and Reality-International (English, Spanish, French)

No. 5 The Markala Cooperative: A New Approach to Traditional Economic Roles-Mali (French)

No. 6 The Working Women's F orum: Organizing for Credit and Change-India (French)

No. 7 Developing Non-Craft Employment for Women in Bangladesh (English, French, Spanish)

No. 8 Community Management of Waste Recycling: The SIRDO-Mexico (English, Spanish)

No. 9 The Women's Construction Collective: Building for the Future-Jamaica (English, Spanish)

No. 10 Forest Conservation in Nepal: Encouraging Women's Participation (English, Spanish, French, Nepali)
No. 11 Port Sudan Small Scale Enterprise Program-Sudan (English)

No. 12 The Muek-Lek Women's Dairy Project in Thailand (English)

No. 13 Child Care: Meeting the Needs of Working Mothers and Their Children (English, Spanish)

No. 14 Breaking New Ground: Reaching Out to Women Farmers in Western Zambia (English, Spanish, French)

No. 15 Self-Employment as a Means to Women's Economic Self-Sufficiency: Women Venture's Business Development Program (English)

No. 16 Wasteland Development and the Empowerment of Women: The SARTHI Experience (French, Hindi)

No. 17 Supporting Women Farmers in the Green Zones of Mozambique (English)

No. 18 Out of the Shadows: Homebased Workers Organize for International Recognition (English)

No. 19 Empowering the Next Generation: Girls of the Maqattam Garbage Settlement (English, Arabic)

No. 20 Women Street Vendors: The Road to Recognition (English)

If you would like additional copies of this issue or any of the editions of SEEDS listed above, send an e-mail to: seeds@popcouncil.org. Copies of selected SEEDS issues in local languages have been published by organizations in the following countries: E gypt, India, Indonesia, Kenya, Nepal, Pakistan, Thailand, and Vietnam. Please write to us for more information if you are interested in these materials. Most past editions of SEEDS are also available online at: www.popcouncil.org/publications. 

